\title{
Pemerintahan Provinsi Lampung 1945-1964
}

\author{
Arizka Warganegara \\ Jurusan Ilmu Pemerintahan FISIP Universitas Lampung \\ e-mail: arizka.warganegara@ fisip.unila.ac.id
}

\begin{abstract}
This is a library research about political elite contestation in Lampung from 1945 until 1964, at that time there are three major ideology, first is Islam, second is Nationalism and third is Communism. In the old orde era, the elite politics competition in the national level describe the same thing with the local level. If in the national level there are three major ideology, in Lampung also three ideology had played important role, the Party Communist (PKI), Indonesian Nationalsit Party (PNI) and Masyumi (Islamic Faction). In the first political stage after Independence of Indonesia. In 1964, there was a first Lampung's Governor Election, at that time R.A Zulkifli Warganegara had appointed to be Lampung first Governor, but because of the political intervention his position was replaced by Koesno Danopoyo which was fully supported by Communist Party. This is a decsriptive qualitative research, the main data comes from indepth interview and documentation. The results shown that there is basic difference between Lampung's political elite contestation in the old orde era and reformation era. In the old orde era the competition based on ideology but in the reformation era the competition based on purely political interest.
\end{abstract}

Keywords: contestation, political elite and election

\section{Pendahuluan}

Pemilihan Gubernur periode kedua Syaharudin Z.P (2009-2014) telah usai, tidak ada sesuatu yang mengkhawatirkan, semua berjalan sukses dan tidak ada gelombang kejut yang diprediksikan akan terjadi sebelum pilgub diselenggarakan, dan yang lebih penting di Lampung telah terjadi sebuah model pembelajaran penting demokrasi lokal di negara ini.

Fantastico dalam bahasa Italia, tujuh pasang calon Gubernur Lampung merupakan yang terbanyak di Indonesia, hal ini berbeda sekali dengan propinsi lain yang rata-rata hanya menghasilkan dua sampai lima calon cagub saja, ditambah lagi dengan adanya dua calon independen.
Namun seiring dengan keheningan, ketenangan pencoblosan dan hasil akhir pleno KPUD, detak politik di daerah ini eskalasinya semakin meninggi saja. Penyebab utama hal ini adalah tuntutan keenam cagub mengenai pro kontra proses dan hasil pilgub. Pertanyaan lanjutannya adalah apakah ini merupakan ke-khas-an politik lokal di Lampung? yang seolah terus berada dalam dilema dan sensasi politik berkepanjangan sejak awal propinsi ini dibentuk.

Jika saya boleh mengurai sedikit sejarah yang tertinggal dalam konteks politik di Lampung, harus diakui memang Lampung memiliki potensi dilema dan sensasi politik yang tinggi, dimulai pada awal tahun 1964 ketika R.A Zulkifli Warganegara memenangkan 
Pemilihan Gubernur Lampung pertama kala itu, dengan mendapat dukungan penuh NU di parlemen lokal. $^{1}$

Namun karena persoalan intrik politik yang sangat ideologis, faksi komunis tidak mendukung. Dan, Soekarno sebagai Presiden RI kala itu menganggap penting untuk menjaga logika politik keseimbangan antara Islam, Nasionalis dan Komunis maka kemudian dilantiklah Koesnodanupoyo sebagai Gubernur Lampung pertama, seorang yang mendapat restu tentunya dari faksi komunis kala itu untuk memimpin Lampung.

Akan tetapi seolah dilema dan keunikan politik lokal di Lampung terus berlanjut, tidak sampai satu periode seorang Koesnodanupoyo mengarungi jabatan empuknya, dan kemudian terlahirlah seorang putra Lampung, Zainal Abidin Pagar Alam, mendapatkan kesempatan untuk memimpin Lampung.

Praktis pasca Gubernur Zainal Abidin Pagar Alam atau lebih tepatnya era Orde Baru, dilema politik dan sensasi elit di Lampung diredam oleh kekuasaan sentralistik Pak Harto, Lampung menjadi satusatunya Propinsi di Sumatera yang pemilihan gubernur selalu melewati logika dropping pusat.

Dalam konteks kekinian, seolah pendulum sejarah itu terulang kembali pasca orde baru runtuh, lebih tepatnya pasca berakhirnya kekuasaan Gubernur Oemarsono (gubernur terakhir dropping-red) eskalasi politik lokal kembali meninggi dan berada dalam dilema dan sensasi politik yang berkepanjangan.

\footnotetext{
${ }^{1}$ Anonim, 100 Tokoh Terkemuka Lampung. Penerbit Lampung Post tahun 2008
}

Berawal dari kontroversi terpilihnya seorang Alzier Dianis Thabranie sebagai Gubernur Lampung yang tidak dilantik oleh Presiden Megawati, dan berujung pada terbitnya SK 15 yang pada waktu itu seolah membuat pemerintahan di Lampung berhenti sejenak.

Pada bagian lain sebagai bagian dari kelanjutan sejarah politik lokal di Lampung, momentum Pilgub 2008 kemarin sebenarnya merupakan waktu yang tepat bagi politik lokal Lampung untuk dapat keluar dari "kutukan" dilema dan sensasi politik selama ini, kemenangan Pasangan Oedin-Joko terhadap keenam pasangan lainnya dengan angka yang lumayan fantastis lebih dari 40 persen, pada awalnya memberikan angin segar bahwa akhirnya Lampung dapat merasakan nikmatnya berpesta demokrasi lokal.

Selain logika dropping Gubernur di era orde lama kemudian dilanjutkan pada era orde barua, serta konflik yang selalu mewarnai setiap kali pemilihan gubernur di provinsi ini. Dalam konteks yang lebih ideologis juga menarik melihat beragam kepentingan elit politik Lampung di era Orde Lama.

Dalam skema kontestasi elit politik lokal di era orde lama, maka logika politik aliran tidak dapat dihidari. Pertarungan elit politik orde lama baik di level pusat sampai dengan provinsi selalu diwarnai dengan kepentingan ideologis antara golongan nasionalis, agama dan komunis.

Kontestasi antar elit di Lampung tercermin misalkan dalam pemilihan Gubernur Lampung yang pertama pada tahun 1964 tersebut. Misalkan golongan NU (Nahdlatul Ulama) dan Masyumi kala itu 
mendukung R.A Zuklkifli Warganegara sementara itu golongan Nasionalis yang berpatronkan dengan PNI (Partai Nasionalis Indonesia) mengusung mantan Residen Lampung, Mr. Gele Harun.

Dalam penelitian ini juga menarik melihat konfigurasi politik aliran dalam ranah konflik dan kompetisi antar elit politik Lampung pada masa itu. Tarik menarik antar golongan nasionalis, agama dan komunis ditambah lagi dengan situasi kisruh politik nasional pada tahun 1964-1965 membuat tensi konflik dan kompetisi antar elit di Lampung pun tidak dapat dihindarkan. Hal inilah yang secara makro menyebabkan beberapa hal positif yang merupakan bagain dari pembangunan demokrasi lokal tidak dapat berkembang dengan baik. Dengan merujuk pada permasalahan ilmiah yang tertera diatas maka ada beberapa hal yang akan diteliti dalam penelitian ini: "Bagaimanakah kontestasi elit politik lokal Lampung di era Orde Lama?"

\section{Pembahasan}

\subsection{Karesidenan Lampung Dalam Sejarah}

Setelah tersusun Pemerintah Keresidenan Lampung Republik Indonesia, segera pula dibentuk KNI Daerah Lampung diketuai R.A. Basyid Warganegara dan cabangcabang KNI Daerah di kewedanaan. Kemudian semua KNI dibubarkan dan dari tahun 1946 dibentuk DPR (Dewan Perwakilan Rakyat) Keresidenan Lampung diketuai A. Yasin (Masyumi), beranggotakan wakil partai dan organisasi rakyat (buruh, tani, pemuda dan wanita) yang ada di kala itu.

Pada tanggal 23 Agustus 1945,

Mr. A. Abbas sebagai anggota
Persiapan Kemerdekaan Indonesia dari Lampung, bersama 2 orang anggota PPKI dari Sumatera Utara, yaitu Mr. Teuku Mohammad Hasan dan Dr. M. Amir, pada tanggal 23 Agustus 1945 bersama-sama berangkat dari Jakarta dengan kapal terbang ke Palembang. Mereka inilah yang membawa berita resmi mengenai Proklamasi Kemerdekaan Indonesia tanggal 17 Agustus 1945. Setelah ketiga anggota PPKI ini bertemu dan berunding dengan Dr. A. K. Gani, seorang tokoh Nasional Perjuangan Kemerdekaan Indonesia, maka malamnya tanggal 23 Agustus 1945 itu juga Mr. A. Abbas melanjutkan perjalanannya dengan kereta api ke Tanjungkarang (Lampung).

Selanjutnya, Mr. A. Abbas segera mengadakan pertemuan dengan tokoh-tokoh dan pemukapemuka masyarakat di Tanjungkarang dan sekitarnya untuk mengambil langkah berikutnya sesuai degan petunjuk dari pemerintah pusat di Jakarta.

Mr. A. Abbas yang ditunjuk sebagai Residen pertama untuk Lampung setelah proklamasi, membentuk Komite Nasional Indonesia Daerah Lampung yang selanjutnya disusul dengan dibentuknya komite-komite Nasional di tingkat Kawedanan dan Kecamatan. Sebagian besar anggota Komite Nasional Indonesia Daerah Lampung, sebagian besar merupakan mantan anggota Susyangikai (semacam DPRD buatan Pemerintah Tentara Pendudukan Jepang) Karesidenan Lampung, yaitu sebagai berikut.

\section{Dewan Pimpinan:}

Ketua : R. A. Basyid Warganegara Wakil Ketua : Dr. Badril Munir 
Sekretaris Umum : R. Suharjo Harjowardoyo

\section{Anggota Dewan:}

1. W. A Rakhman

2. Mr. Gele Harun

3. A. Aziz Gustam

4. A. Aziz Cindarbumi

5. K. H. Harun

6. K. H. Ali Tashim

7. Syamsuddin

8. Abdullah Suhaili

9. A. Yasin

10. Sumarno

11. Suwardi

12. R. Pagar Alam

13. K.H Nawawi

14. dr. Drajat

\section{Badan Pekerja:}

1. Ketua W. A. Rakhman

2. Wakil Ketua Mr. Gele Harun

3. Sekretaris Umum

A.

Aziz Cindarbumi

4. Sekretaris I : Aziz Rauf

5. Sekretaris II : A. Khalik Shahib

6. Bendahara: Kgs. A. Solikhin

7. Perlengkapan: H. Zainal Nuh

Pada tanggal 5 September 1945, keluarlah sebuah instruksi dari Pemerintah Pusat untuk dilakukan pengambilalihan kekuasaan di kawedanan-kawedanan, serta pengibaran bendera Merah Putih secara menyeluruh, dengan penjagaan seperlunya.

Setelah Mr. A. Abbas berunding dengan beberapa pejabat kantor Karesidenan Lampung, antara lain Sultan Rahim Pasaman dengan pihak Residen Lampung, maka pihak pemerintah Jepang (Syukocan) bernama Kobayashi, bersama dengan beberapa pejabat Jepang, menyerahkan kekuasaan kepada Mr. A. Abbas selaku Residen Lampung dari Pemerintah Republik Indonesia.
Adapun susunan Pemerintah Republik Indonesia yang pertama dari Karesidenan Lampung adalah sebaga berikut.

Residen : Mr. A. Abbas

Pembantu : Sutan Rahim Pasaman

Sekretaris: A. Lumban Tobing

Kepala Kepolisian : R. Suharjo Harjowardoyo

Kepala Kehakiman : Mr. Gele Harun

Kepala Kantor Kemakmuran/ Ekonomi : Kgs. A. Somad Solikhin

Kepala Kantor Penernagan : Amir Hasan

Kepala Kantor Kehewanan: Dr. Samil

Kepala Kantor PU: Mas Sahid

Kepala Kantor Kesehatan: Dr. Kajat

Kepala Kantor Pos Besar : Lim Ceng Kieng

Kepala Kantor Telepon/ Paragraf : M. Nur

Kepala Jawatan Kereta Api : Ibrahim Kepala Kantor Agama : $\quad$ K. H. Muhammad Thoha

Pada bulan februari tahun 1946, tentara Jepang yang menduduki daerah Lampung telah selesai seluruhnya meninggalkan Lampung menuju Palembang. Namun demikian, sejak negara Republik Indonesia diproklamirkan, sisitem pemerintahan Jepang masih diteruskan. Pada Surat Keputusan Gubernur Sumatera (Medan) tanggal 17 Mei 1946 No. 113, Karesidenan Lampung dibagi menjadi 3 Kabupaten, 11 Kawedanan. Setiap Kawedanan dibagi atas beberapa Kecamatan dan setiap Kecamatan dibagi lagi menjadi beberapa Marga.

Kabupaten-kabupaten dan Kawedanan-kawedanan di daerah Karesidenan Lampung itu adalah:

A. Kabupaten Lampung Utara dengan Kawedanan: 
1. Kawedanan Menggala

2. Kawedanan Kotabumi

3. Kawedanan Way Kanan

4. Kawedanan Krui

Dengan Bupatinya adalah

\section{Burhanuddin}

B. Kabupaten Lampung Tengah, dengan Kawedanan

1. Kawedanan Sukadana

2. Kawedanan Metro

3. Kawedanan Way Seputih

Zainabun

Dengan Bupatinya adalah

C. Kabupaten Lampung Selatan, dengan Kawedanan

1. Kawedanan Kalianda

Kawedanan Telukbetung

2. Kawedanan Kedondong

Dengan Bupatinya adalah R.A Basyid Warganegara

Pada 10 September 1946, terjadilah suatu rapat raksasa di Lapangan Enggal Tanjung Karang yang diadakan oleh Panitia Perbaikan Masyarakat (PPM), yang tokohtokoh penggeraknya antara lain: Abdullah Sani, Abdul Kohar, dan sebagai pembicaranya adalah Zainal Abidin. Mereka mendesak agar Mr. A. Abbas segera turun dari jabatannya dan digantikan oleh Dr. Badril Munir sebagai Residen Lampung, dan wakilnya adalah Ismail. Selanjutnya, Pemerintahan Karesidenan Lampung diambil alih oleh Komandan Resimen III Letkol M. Arief, dan diberikan kepada Dr. Badril Munir dan Ismail sebagai wakilnya, sambil menunggu keputusan dari Pemerintah Pusat.

Kemudian, pada tanggal 29 Oktober 1946, Mr. Hermani dari Pemerintah Pusat melalui Palembang datang ke Tanjung Karang untuk menyelesaikan kekalutan masalah ini. Oleh Pemerintah Pusat, disetujui bahwa Dr. Badril Munir menjadi Residen Lampung, tetapi Ismail tidak dapat diterima menjadi Wakil Residennya. Selanjutnya, ditugaskanlah R. M. Rukadi Wiryoharjo dari Jakarta sebagai Wakil Residen Lampung. Mereka menjabat hingga pada tanggal 29 November 1947 Dr. Badril Munir meletakkan jabatannya, dan diganti oleh R. M. Rukadi Wiryoharjo sebagai Residen Lampung yang baru. Adapun yang menjabat sebagai Wakil Residen adalah R. A. Basyid Warganegara.

Pada bulan Agustus 1945 sampai dengan pertengahan tahun 1947, Sumatera merupakan satu propinsi, uang dipimpin oleh gubernur M. Teuku Muhammad, yang berkedudukan di Medan, Sumatera Utara. Pada pertengahan tahun 1947, Propinsi Sumatera dibagi menjadi 3 (tiga) sub Propinsi, yaitu:

1. Sub Propinsi Sumatera Utara di Medan

2. Sumatera Tengah di Bukittinggi

3. Sumatera Selatan di Palembang

Karesidenan yang masuk Sub Propinsi Sumatera Selatan, ialah Karesidenan Palembang, Karesidenan Lampung, karesidenan Jambi, Karesidenan Bengkulu, dan Karesidenan Bangka Belitung. Pada tanggal 5 Mei 1947, Pemerintah mengeluarkan sebuah dekrit yang berisi perintah untuk mempersatukan semua kekuatan bersenjata, yaitu TRI dan laskar-laskar atau badan pejuang.

\subsection{Pergulatan Ideologi Elit Orde Lama Lampung}

Sejarah demokrasi Indonesia selalu melewati fase 20 tahun-an. Dimulai pada tahun 1908 adalah masa konsolidasi awal, kemudian 
pada tahun 1928 seluruh pemudapemudi jong java, jong sumatera, jong bugis dan lainnya berkumpul untuk menyatakan diri dalam satu perikatan berbahasa, berbangsa dan bertanah air satu Indonesia, tidak tepat 20 tahun, tepatnya 1945 sejarah bangsa ini dimulai dengan sebuah proklamasi kemerdekaan walaupun tahun ini sebenarnya tetap menjadi sebuah kontroversi sebab buat penjajah Belanda pengakuan kemerdekaan dan kedaulatan Indonesia baru terjadi pada tahun 1948. Pada tahun 1965 terjadi sebuah peristiwa yang menggemparkan kala itu penumbangan rezim orde lama kepada rezim orde baru.

Kemudian pada tahun 1985 terjadi sebuah guncangan ekonomi akibat banyak pengangguran pada masa itu, banyak lulusan perguruan tinggi tidak mendapatkan pekerjaan yang layak sebagai seorang sarjana. Kemudian tidak tepat 20 tahun, pada tahun 1998 terjadilah sebuah reformasi politik dengan tumbangnya rezim orde baru. Demokratsiasi dimulai, persoalan-persoalan otoritarianisme dalam bidang politik dan sosial kemasyarakatan mulai direformasi.

Lebih dari 9 (sembilan) tahun semenjak 1998 sampai dengan sekarang, bangsa ini telah mengalami era demokratisasi akan tetapi ternyata disebalik itu banyak sekali terjadi fase-fase yang tidak terprediksi dan terkadang menjadikan demokrasi sebagai pembenar dari tindakan yang anarki dan tidak bermanfaat. Oleh sebab itu kita perlu sebuah konsep demokrasi yang aplikatif dan berdasarkan pada nilai-nilai ke-Indonesia-an.

Permasalahan sejarah dan kontemporer Sistem Politik Indonesia adalah belum adanya sebuah nilai demokrasi yang diyakini sebagai bagian dari nilai KeIndonesia-An. Selama ini demokrasi hanya dilihat sebagai bagian dari rutinitas prosedural saja bukan substansi yang harus diyakini dan kemudian dijalankan oleh elemen bangsa.

Kontestasi politik lokal tidak terlepas dari kontestasi elit politik nasional. Pada bagian penulis akan mendahului dengan menerangkan selintas mengenai Politik Indonesia di era orde lama. Pada masa itu (era 1945-1964) di level nasional telah terjadi 2 (dua) model demokrasi yaitu model demokrasi liberal parlementer dan model demokrasi terpimpin. Beberapa ciri dari demokrasi liberal yang paling mencolok adalah karena harus mengakomodasi banyak partai maka sistem pemerintahannya adalah sistem yang parlementer.

Selama sistem politik yang liberal tersebut tercatat beberapa kali pergantian pemerintahan. Diawali dengan Pemerintahan PM Syahrir (14 November 1945- 27 Juni 1947), kedua di bawah Pemerintahan PM Amir Syarifudin ( 3 Juli 1947 - 29 Januari 1948), Pemerintahan PM M. Hatta ( 29 Januari 1948 - 20 Desember 1949). Pada era PM M.Hatta terjadilah Konferensi Meja Bundar di Den Haag Belanda (23-29 Okt'49) Indonesia mengalami perubahan bentuk negara dari Kesatuan (unitaris) menjadi negara federal sesuai dengan UUD RIS. NKRI salah satu dari 16 negara yang berfederasi dengan RIS. Dan kemudian pada tanggal 15 Agustus 1950 pengesahan UUD Sementara, Indonesia kembali menjadi negara kesatuan.

Selanjutnya Kabinet di pimpin oleh Natsir (6 September 1950 - 27 
April 1951), Kabinet SukimanSuwirjo (27 April 1951 - 3 April 1952), Kabinet Wilopo - Prawoto (3 April 1952 - 30 Juli 1953), Kabinet Ali Sastroamijoyo ( 30 Juli 1953 12 Agustus 1955 ), Kabinet Burhanuddin Harahap ( 12 Agustus 1955 - 24 Maret 1956 ), Kabinet Ali Sastroamijoyo II (24 Maret 1946 - 9 April 1957), dan kemudian diakhiri oleh Kabinet Karya Djuanda (Kabinet Extra Parlementer) terhitung 9 April 1957 - 9 Juli 1959.

Dalam konteks lembaga legislatif tercatat tiga bentuk institusi legislatif yang pernah berdiri yaitu KNIP (Komite Nasional Indonesia Pusat) yang berdiri pada tanggal 29 Agustus 1945 s.d 15 Februari 1950, kemudian DPR RI 15 Februari 1950 s.d 16 Agustus 1950 dan DPR Sementara terhitung tanggal 17 Agustus 1950 - 26 Maret 1956

Beberapa partai politik yang ada antara lain:

a. Partai Nasional Indonesia (PNI ) Ketua : Ir. Soekarno

b. Partai Komunis Indonesia (PKI) Ketua : M. Jusup

c. Masjumi

Ketua : dr. Sukiman Wirjo

d. Partai Buruh Indonesia (PBI) Ketua : Nyono

e. Partai Rakjat Djelata Ketua : Sutan Dewanis

f. Partai Kristen Indonesia (Parkindo) Ketua

Probowinoto

g. Partai Sosialis Indonesia (PSI) Ketua : Amir Sjarifuddin

h. Partai Rakyat Sosialis (Parsi) Ketua : Sutan Sjahrir

Era demokrasi terpimpin dimulai semenjak Presiden Soekarno mengeluarkan Dekrit Presiden ,pada tanggal 5 Juli 1959, yang berisikan mengenai

Pembubarkan
Konstituante, Menetapkan UUD 1945 berlaku bagi segenap bangsa Indonesia dan menyatakan tidak berlakunya lagi UUD 1950 dan Membentuk MPRS yang terdiri dari anggota-anggota DPR, utusan daerah-daerah dan utusan golongangolongan.

Jika pada demokrasi liberal sistem pemerintahan yang harus mengakomodasi banyak kepentingan maka dalam sistem demokrasi yang terpimpin oleh sebab Soekarno menjadi nilai tunggal sistem pemerontahan pun berubah menjadi sistem presidensil. Dalam sistem ini presiden mempunyai peran besar dalam pengaturan konfigurasi kekuasaan dalam kabinet.

Pada masa demokrasi terpimpin terdapat dua kabinet, Kabinet Presidensial disebut sebagai Kabinet Kerja I masa kerja 10 Juli 1959 s.d 18 Februari 1960, Kemudian dilanjutkan Kabinet Kerja II dengan struktur kabinetnya sama dengan struktur kabinet Kerja I. istilah yang terkenal untuk kedua kabinet ini adalah kabinet Dwikora dan Kabinet Ampera

Lembaga legislatif merupakan hasil pemilu pertama, DPR hasil Pemilu 29 September 1955 yang bertugas sejak 26 Maret 1956 s.d 5 Maret 1960, kemudian dilanjutkan oleh DPR Gotong Royong yang bertugas sejak 24 Juni 1960 s.d 19 November 1966. Sementara itu di era terpimpin pada pemilu pertama partai peserta pemilu tahun 1955 berjumlah 118 partai politik, diantaranya adalah PNI, Masjumi, NU, PKI, PSII, Parkindo, Partai Katholik, PSI, dan lainnya.

Pada era orde lama kompetisi ideologi di pusat juga merupakan bagian dari cermin politik lokal dan persaingan ideologi di Lampung, 
PNI, PKI, NU dan Masjumi merupakan partai-partai politik yang berkuasa di Lampung. Hasil pemilu nasional 1955 juga merupakan cerminan hasil pemilu lokal di Lampung tahun 1955.

Nasionalis, Islam dan Komunisme merupakan 4 (empat) aliran ideologi yang dominan di Lampung. Dominasi ketiga ideologi itu sama dengan konfigurasi kekuatan parpol di pusat. Pemilu 1955 menghasilkan empat kekuatan politik besar, yakni PNI, Masyumi, NU, dan PKI, yang meraih $77 \%$ dari kursi DPR. Kabinet hasil Pemilu adalah koalisi PNI dan Masyumi di bawah PM Ali Sastroamidjojo dari PNI. Namun, stabilitas pemerintahan yang diharapkan dari pemilu pertama itu tidak tercapai. Kabinet ini hanya bertahan setahun karena banyak menghadapi benturan dengan kekuasaan presiden serta pergolakan di daerah (Lampost, 11 Desember 2008).

Situasi politik itu sama dengan kondisi di Lampung seperti yang dijelaskan oleh Pangeran Nur sebagai salah satu tokoh pada masa itu:

Saya kurang jelas kalau di tingkat pusat, kalau di tingkat Lampung ini NU pada waktu itu yang agak tenar. Sebab pada waktu itu anggota DPRnya kebanyakan dari NU, PNI, PSII, IKIP, Masyumi pada waktu itu sudah dibekukan atau belum ya. Saya masa kecilnya tidak ke zaman Masyumi (Wawancara, 1 Desember 2009)

Kemudian hal itu juga didukung oleh pernyataan dari Dr. Arifin Nitipradjo:

Pada waktu itu PNI yang lebih banyak, disusul oleh PKI. Masyumi juga ada. Tapi Masyumi juga ada, tapi Masyumi juga kebetulan kelihatan sudah agak lemah, ya terus terang saya katakan agak lemah, sehingga tertinggal oleh PKI ini, dan PKI memang menjalankan taktik mereka bagaimana juga supaya dapat menang. Tapi untung saja masih dapat diatasi oleh PNI. Masyarakat masih percaya terutama pada waktu itu adanya pengaruh Bung Karno. Ketua Masyumi waktu itu Basyid kebetulan beliau itu ditunjuk sebagai anggota DPR, dari Lampung, dari Sumatera Selatan pada waktu itu. Dan kebetulan Lampung mendapat suara juga, sehingga Basyid itulah yang jadi wakil Masyumi pada waktu itu. Seingat saya Pak Basyid itulah. (Wawancara, 1 Desember 2009)

Pada masa itu memang tiga ideologi besar yang menguasai konfigurasi kekuatan politik di Lampung. Ideologi nasionalis yang diwakili oleh PNI (Partai Nasionalis Indonesia), Masjumi dan NU (Nahdlatul Ulama) yang mewakili Ideologi Islam dan PKI (Partai Komunis Indonesia) yang mewakili ideologi komunisme.

Pada era orde lama PNI mendominasi parlemen di Lampung pada sisi lain dominasi PNI dan ideologi nasionalisme juga disebabkan oleh Peran Masjumi yang sudah melemah, pada satu sisi melemahnya peran Masjumi itu disebabkan oleh dua hal pertama adalah menguatnya PNI dan PKI, kedua keberpihakan Soekarno pada dua ideologi diluar Islam menjadi pemicu lanjutannya.

Pada bagian lain melemahnya Ideologi Islam dalam partai politik di era orde lama juga disebabkan oleh di era orde lama masjumi sempat dibekukan oleh Pemerintah dalam hal ini melalui Kepres Soekarno. Sehingga dalam konteks kepolitikan lokal di Lampung-pun Masjumi menjadi partai yang tidak lagi 
mendominasi, hal ini sama dengan pernyataan Pangeran Nur bahwa memang pada tahun akhir 1940-an sampai dengan awal tahun 1950-an Masjumi dibekukan oleh Pemeritah Orde Lama.

Oleh karena Masjumi dibekukan atau dalam bahasa politik sedikit dilumpuhkan perannya dalam politik, maka dalam konteks Lampung, Partai yang berbasisi ideologi Islam lainnya seperti NU mengambil peran sebagai representasi Partai Islam dalam struktur pemerintahan lokal dan nasional. Seperti halnya pernyataan dari Pangeran Nur sebagai berikut:

Masyumi dengan NU dulu bersatu. Sebetulnya, ya sesudah Masyumi dibekukan, maka kekuatan Islam dominan di NU. Sesudah G30 SPKI, NU ini muncul. Semua pejabat, dapat dibilang orang NU semua, sampai Bupati. Sampai Mendagri, Basuki Rachmat dulu 'kan ada hubungan dengan NU. (Hasil Wawancara, 1 Desember 2009)

Setelah Masjumi perannya dilemahkan oleh pemerintah maka NU (Nahdlatul Ulama) secara otomatis mengambil peran partai yang berbasis Islam, apalagi posisi ini diperparah dengan peran PKI yang semakin hari semakin dominan dalam ranah politik orde lama. Ketika masjumi melemah maka peran-peran partai Islam berada dalam pundak NU, hampir semua pejabat pemerintahan sampai dengan Bupati mempunyai keterkaitan hubungan dengan NU.

Mengenai dominannya peran NU dalam politik Lampung pada waktu itu yang menggantikan peran Masjumi juga dijelaskan lebih lanjut oleh Pangeran Nur:

Di pusat, kerjasama antara Idham Cholid dengan Sukarno agak kuat, sampai ke Suharto. Sebab kejayaan NU itu pada masa Idham Cholid. Kemudian dalam konteks Lampung, satu dua dengan PNI dan NU (Wawancara, 1 Desember 2009)

Pada posisi ini sangatlah jelas bahwa dalam konteks Lampung di era Orde Lama ada tiga golongan partai yang sangat dominan di Lampung yaitu PNI, PKI dan NU, sementara itu pada posisi tertentu peran Masjumi yang dahulu sejak kemerdekaan atau dalam era demokrasi liberal begitu dominan sebagai perwakilan partai Islam dalam peta konfigurasi kekuatan politik Indonesia di masa tersebut. Hal ini dapat terjadi karena pada masa itu pimpinan NU KH. Idhan Cholid mempunyai hubungan yang erat dengan Soekarno yang menjabat presiden sekaligus sebagai "pembesar" dari PNI, relasi khusus ini yang kemudian menyebabkan kerjasama antara PNI dan NU juga dapat berjalan dengan baik.

Oleh sebab NU adalah menganut ideologi Islam, maka fatsoen politik tetap menjadi border line yang jelas bagi kader-kader NU kala itu berpolitik. Prinsip politik tidak ada saling menjegal, toleransi, kompromi dan berlandaskan pada ukhuwah. Sesuai dengan pernyataan dari Pangeran Nur:

Secara garis besar NU penyatuan, gap tidak ada, orang itu digiring ke doa. Kala NU dulu sebenarnya bertentangan dengan Masyumi, tapi tidak, jadikan satu. Sebab kita ahlussunnah Rois Am begitu dominan, ia berkuasa tunggal. Berkiblat kepada Al-Qur'an dan hadits. Kompormi, apapun selesai dengan Presiden Soeharto, apapun dengan Soekarno, KH. Wahab ini menyelesaikannya. Cuma dulu yang nggak mau Masyumi mengajak 
berontak, dia tidak mau. (Wawancara, 1 Desember 2009)

Dalam konteks tertentu sebenarnya pada masa itu diantara kelompok ideolog Islam sekalipun terjadi sebuah persaingan, secara sederhana antara NU dan Masjumi walaupun berasas islam akan tetapi tetap saja pada masa itu terjadi persaingan politik. Dasar persaingan politik antara NU dan Masjumi pada waktu itu adalah persoalan kepahaman akan nilai islam, masjumi menganggap membawa konsep revitalisasi islam dan politik sementara itu pandangan NU dan politik pada masa itu terlihat masih cenderung konservatif. Pada bagian inilah antara NU dan Masjumi tidak bisa menyatu. Ketika Masjumi dibekukan oleh Soekarno atas desakan PKI maka NU sebagai Partai Islam dengan cepat mengambil peran Masjumi.

Begitu dominannya PNI dalam kursi di Parlemen nasional dan lokal di era tersebut ternyata tidak menjadikan partai ini dominan pula dalam akar rumput, justru PKI yang menjadi partai yang mendominasi akar rumput pada masa itu karena PKI mempunyai sel-sel politik di setiap kelompok kepentingan yang ada seperti misalnya PKI mempunyai kelompok pengaderan di kalangan petani dan buruh, hal ini sesuai dengan penjelasan oleh Pangeran Nur:

Sebelum tahun 1965 yang menonjol PKI. Sebab PKI ini dapat dikatakan kuat kerjanya di bawah. Massanya dari petani dan segala macam, itu kan banyak massanya. Dapat dibilang dia 'kan bisa terikat dengan petani. Petani mudah sekali dipengaruhi olehnya. Sebab massa itu 'kan banyak petani. Semua petani itu lari ke PKI, sebab yang membagi- bagi tanah dulu 'kan PKI.

(Wawancara, 1 Desember 2009)

Selain dengan menggunakan kelompok-kelompok pengaderan, cara lain yang dilakukan PKI adalah dengan menggunakan strategi politik pertanahan. Peran sentral PKI dengan membagi-bagikan tanah pada para petani adalah cara lain yang digunakan PKI untuk meraih simpati massa akar rumput pada waktu itu.

Selain mendominasi dengan menggunakan buruh dan petani beberapa organisasi PKI juga digunakan untuk mempengaruhi pelajar, seperti ideologisasi IPPI atau dikenal Ikatan Pelajar Indonesia, merujuk hasil wawancara dengan Arifin Nitipradjo Tegamoan:

Ya, setelah pemilu 1955 juga memang dominan sekali PNI, tetapi boleh dikatakan PKI itu yang paling banyak menyelusup. Kita tahu dia menyelusup ya, untuk masuk ke semua partai ini. Jadi korban waktu itu saya aktif di IPPI, banyak sekali anggota-anggita kita itu, pelajarpelajar itu diselusupi dipengaruhi oleh Pemuda Rakyat waktu itu dan juga IPPI di situ ada IPPI perguruan tinggi ya, karena IPPI perguruan tinggi itu sendiri, jadi pada mahasiswa itu adlah IPPI perguruan tinggi, istilahnya. Itu banyak betul tersusupi oleh Pemuda Rakyatnya. Sehingga pada tahun 1950 untuk pemilu itu tahun 1955 kita ini boleh dikatakan jadi rebutan antara partaiPartai itu, dimana partai itu gencar sekali akan mendirikan anak partailah, anak-anak muda itu. Saya dipengaruhi segala macam dengan janji-janji yang kebetulan pada waktu itu baru menjelang mahasiswa baru masuk sampai dipengaruhi segala macam, tapi untung saja saya tidak terpengaruh. Tetapi pada waktu Kongres Pemuda sedunia di Beijing 
waktu itu, kita IPPI mengirimkan bukan berupa peserta, tapi peninjau. Itu IPPI Ketua DKI, namanya Edi Abdurrahman. Saya waktu itu DKI, orang DKI. Tapi saya sangat kaget sekali sepulangnya dari Beijing itu, belum mendarat di Lapangan Kemayoran, teman-temannya sudah menghembuskan. Bahwa Edi Abdurrahman itu sudah membawa jubah merah, istilahnya. PKI-lah. Dan memang boleh dikatakan, waktu hadir kesana itu ya, dia itu sudah mendapat pesan-pesan dari PKI barangkali. Sehingga, termasuk saya sangat menolak pendapatpendapatnya yang akan dibawa ke Jakarta inilah, ke Indonesia. (Wawancara, 1 Desember 2009)

Proses ideologisasi IPPI oleh PKI kemudian menyebabkan banyak pelajar secara tidak sadar menjadi bagian dari keanggotaan PKI. Pada masa itu PKI begitu cerdas dan cerdiknya para punggawa PKI sehingga bisa memanfaatkan kekosongan ideologi para pelajar tersebut dan akhirnya mempengaruhi mereka untuk menjadi bagian dari PKI. Pada masa itu banyak sekali pelajar yang tidak menyadari bahwa mereka telah menjadi bagian dari PKI, karena PKI dengan cerdas menggunakan strategi sel-sel ideologi sehingga strategi menarik massa PKI nyaris tidak kelihatan sebagai bagian dari strategi politik PKI.

Pada bagian lain persaingan ideologi ditingkat pusat justru membuat kerangka persaingan yang sama pada politik di Provinsi Lampung, "kemesraan politik" antara NU dan PNI mulai memudar karena ada persaingan antara Soekarno dan Wahid Hasyim, pada Pemilu 1955 ketua NU kala itu K.H Wahid Hasyim mencalonkan diri menjadi
Presiden, sesuai dengan hasil wawancara dengan Pangeran Nur "Pemilu 1955 memang banyak juga, kuat juga PKI. Pada 1955, Wahid Hasyim 'kan mencalonkan presiden, namun ditabrak di Bandung." Terlepas benar tidaknya adanya konspirasi untuk menggulingkan pencalonan Wahid Hasyim dengan cara kecelakan yang penuh dengan rekayasa tersebut.

Kemesraan antara elit-elit politik faksi ideologi Nasionalis dengan Islam mulai memudar pasca pemilu 1955, dalam konteks Lampung kemesraan itu tidaklah luntur justru pada masa itu ada 11 (sebelas) partai politik secara bersama kompak untuk mendukung terbentuknya Provinsi Lampung, sesuai dengan pernyataan dari Ariin Nitipradjo Tegamoan :

Yang pokok pada waktu itu karena dititikberatkan ya, 11 partai ini kompak untuk mendukung berdirinya propinsi. Terutama yang dipelopori oleh Partai PNI lah, Nasional. Pada waktu itu memang betul PNI memang betullah dominan pada waktu itu. Nah, itulah saya katakan, mungkin karena hubungan baik tadi. Ideologi itu seolah-olah tidak bertentangan, karena hubungan baik antara mereka ini. Terutama di Lampung, kalau saya perhatikan, hubungan keluarga, hubungan satu sama lain, hubungannya baik sekali. Meskipun ada Masyumi, ada PKI, ada PNI. Cuma boleh dikatakan yang keras itu antara Masyumilah dengan PKI. Kalau kita banding-bandingkan keseluruhannya, Masyumi dengan PKI inilah. Ditambah lagi setelah PKI dapat angin, dapat dukungan besar dari PNI, disitulah, mulai beranjaknya, sampai tahun 1955 itu, sehingga PKI boleh dikatakan hebat sekali. Karena PKI yang diketuai 
oleh Aidit pada waktu itu, sekeluarga besar termasuk adik-adiknya Sobron Aidit, sangat aktif dalam hal itu. Saya sangat betul dengan adiknya Ilaih Sobron Aidit, tapi entah kemana dimana sekarang, tidak tahu. Tinggal nama saja itu. (Wawancara, 1 Desember 2009)

Persaingan ideologi di Lampung justru terlihat antara PKI dan Masjumi, atas dorongan PKI lah yang kemudian membuat Soekarno membekukan Masjumi, justru pada akhirnya sementara PNI memang menguasai parlemen. Pertarungan ideologi yang terasa di Lampung adalah persaingan antara PKI dan Masjumi antara ideologi Islam dan Komunisme. Sesuia dengan pernyataan Arifin Nitipradjo Tegamoan:

Nah, itulah saya katakan, mungkin karena hubungan baik tadi. Ideologi itu seolah-olah tidak bertentangan, karena hubungan baik antara mereka ini. Terutama di Lampung, kalau saya perhatikan, hubungan keluarga, hubungan satu sama lain, hubungannya baik sekali. Meskipun ada Masyumi, ada PKI, ada PNI. Cuma boleh dikatakan yang keras itu antara Masyumilah dengan PKI. Kalau kita banding-bandingkan keseluruhannya, Masyumi dengan PKI inilah. Ditambah lagi setelah PKI dapat angin, dapat dukungan besar dari PNI, disitulah, mulai beranjaknya, sampai tahun 1955 itu, sehingga PKI boleh dikatakan hebat sekali. Karena PKI yang diketuai oleh Aidit pada waktu itu, sekeluarga besar termasuk adik-adiknya Sobron Aidit, sangat aktif dalam hal itu. Saya sangat betul dengan adiknya Ilaih Sobron Aidit, tapi entah kemana dimana sekarang, tidak tahu. Tinggal nama saja itu. (Wawancara, 1 Desember 2009)
Pernyataan itu menjadi sesuatu yang mesti kita renungi terutama bagi persaingan elit-elit politik Lampung dimasa sekarang ini. Bagaimana para tokoh politik senior Lampung berhasil meredam persaingan politik aliran yang cukup tinggi dengan hanya mengandalkan jiwa besar dan berlandas pada fatsoen politik yang dipegang bersama.

\subsection{Kontestasi Politik Elit Lampung Orde Lama}

Menurut Pangeran Nur (Sekretaris Wilayah NU Pertama Lampung) bahwa revolusi di Lampung dimulai pada era tahun 1940-an, hal ini disampaikan beliau dalam sebuah wawancara, ada beberapa tokoh yang merupakan tokoh-tokoh revolusi di Lampung antara lain Mr. Abbas, Nur Effendi, Abdul Kadir Raja Rimba dan tokohtokoh lainnya. Tokoh-tokoh inilah yang menjadi ikon dari perjuangan revolusi fisik di Lampung.

Politik itu sebenarnya begini. Sepengetahuan saya di waktu revolusi, $\mathrm{Mr}$ Abbas itu pelopor revolusi. Memang dulu perjuangan ini terbagi dua. Saya masih kurang jelas pemimpinnya itu masih terbentuk Sukardi cs., Mas Adi mereka itu, Nur Effendi. Sebelah selatan dulu yang memimpin perjuangan dulu Almarhum Abdul Kadir Raja Rimba, sekutu pahlawan Radin Inten. (Wawancara, 1 Desember 2009)

Setelah itu relatif bahwa pertarungan elit politik di Lampung terjadi lagi pasca pemilu 1955, pada saat itu seperti halnya hasil dipusat di daerah termasuk Lampung, PNI menjadi pemenang pemilu pertama untuk wilayah Lampung diikuti oleh 
PKI dan kemudian Masjumi. Sepertihalnya yang diungkap oleh Arifin Nitipradjo Tegamoan:

Pada waktu itu memang pertama kali dulu, waktu itu, kongres kita masih sangat memperjuangkan 17 Agustus. Jadi, semua partai itu boleh dikatakan sangat dikerahkan untuk mempertahankan perjuangan proklamasi 17 Agustus. Pada waktu itu peran Masyumi cukup kuat. Tetapi karena gerakan2nya ini sangat teratas, masih bisa dikonter oleh PKI, karena PKI ini terus-menerus memperjuangkan dirinya supaya dapat suara terbanyak untuk mendapat daerah pemilihan nanti, tahun 1955 itu ya. Sehingga mereka itu menyelusup ke bawah semua. Sebenarnya, Masyumi pada waktu itu cukup kuat. Masyumi, PNI, baru PKI-lah. Ya itulah urutannya. (Wawancara, 1 Desember 2009)

Dalam konteks tertentu Soekarno yang memang dekat dengan masa beraliran komunis karena dia sendiri mengganggap dirinya sebagai Marhenis maka dalam dimensi kerjasama politik Soekarno pada masa itu lebih dekat dengan faksi komunis dibandingkan dengan Islam, kedekatan Soekarno dengan faksi Islam baru terjadi manakala Masjumi telah dibekukan dan Idham Chalik membina hubungan yang intens dengan dirinya.

Hal itulah yang menjadi penyebab awal hubungan kerjasama politik antara elit-elit partai yang beraliran nasionalis agak sulit untuk bekerjasama dengan elit-elit politik yang beraliran Islam, akibatnya ketika pemilihan Gubernur Lampung pertama kali tahun 1964, kader NU R.A Zulkifli Warganegara yang telah terpilih di Parlemen tidak dilantik oleh Soekarno karena alasan faksi komunis tidak menyetujui. Hal ini sesuai dengan wawancara dengan Pengeran Nur sebagai berikut:

Itu dicalonkan NU, tapi karena dia menang dicegat PKI, tidak jadi diangkat menjadi Gubernur. PKI pernah dia tadinya menang, dalam pemilihan gubernur. Tapi karena dicegat oleh PKI di Pusat, yaitu Subandrio, dibatalkan hasil pemilihan, diggugat, dipilih kembali. Karena PKI masih dominan. Masyumi dan NU belum kuat menandingi PKI, karena PKI masih cukup kuat. PKI menguasai petani. Massanya yang paling besar adalah PKI. Pemimpinnya Juned Suropati. Tapi ada juga, orang dari Jawa Barat yang aktif, dan orang Batak. Sebab staf PKI di Kampung Sawah dulu, NU-lah yang mengambil alih. Setelah G30 SPKI meletus, NU berperan untuk membantu ABRI. Tapi, sebelum itu, gubernur pertama Lampung ini Zulkifli. PKI sangat dominan. NU baru muncul waktu PKI ditumpas dan Masyumi dibekukan. NU pertama di Lampung di Bandar Lampung H. Marhasan SS., saya Sekwil. Setelah Marhasan diganti Kiai Zahri. (Wawancara, 1 Desember 2009)

Perihal pencegatan oleh faksi komunis terhadap pelantikan Gubernur terpilih pertama ini juga diungkapkan oleh R.A Zulkifli Warganegara sebagai berikut "Semua menyusulkan saya menjadi Gubernur Lampung tahun 1964, kecuali PKI. Cuma satu aja, saya tidak mengerti. Saya belum pulang, sudah ribut untuk itu." Faksi komunis tidak bersetuju karena sosok Zulkifli yang didukung oleh NU dibawah Pimpinan Wilayah kala itu Hi. Narhasan SS dan Sekretaris Pangeran Nur, dianggap sebagai representasi golongan Islam, dan 
pada masa itu Soekarno juga berada dalam dilema untuk menjaga politik keseimbangan sebagai Presiden yang tetap memerlukan dukungan politik dari PKI. Kita juga ingat misalnya bagaimana politik keseimbangan yang coba dimainkan oleh Soekarno pada akhirnya tidak maksmal sehingga terjadinya pemberontakan G-30 S/PKI tersebut:

Persoalan ketidaksetujuan PKI atas Pelantikan R.A Zulkifli Warganegara sebagai gubernur pertama Lampung karena persoalan persaingan ideologis anatra elit Islam dan PKI juga diungkapkan oleh Pangeran Nur sebagai berikut:

R.A Zulkifli Warganegara itu dicalonkan NU, tapi karena dia menang dicegat PKI, tidak jadi diangkat menjadi gubernur. dia tadinya menang, dalam pemilihan gubernur. Tapi karena dicegat oleh PKI di Pusat, yaitu Subandrio, dibatalkan hasil pemilihan, diggugat, dipilih kembali. Karena PKI masih dominan. Masyumi dan NU belum kuat menandingi PKI, karena PKI masih cukup kuat. PKI menguasai petani. Massanya yang paling besar adalah PKI. Pemimpinnya Juned Suropati. Tapi ada juga, orang dari Jawa Barat yang aktif, dan orang Batak. Sebab staf PKI di Kampung Sawah dulu, NU-lah yang mengambil alih. Setelah G30 SPKI meletus, NU berperan untuk membantu ABRI. Tapi, sebelum itu, gubernur pertama Lampung ini Zulkifli Warganegara. PKI sangat dominan. NU baru muncul waktu PKI ditumpas dan Masyumi dibekukan. NU pertama di Lampung di Bandar Lampung H. Marhasan SS., saya Sekwil. Setelah Marhasan diganti Kiai Zahri.(Wawancara, 1 Desember 2009)
Hal ini juga sama dengan yang diungkapkan oleh R.A Zulkifli Warganegara sebagai berikut:

Ini sudah permintaan Soekarno sehingga Danupodjo yang di-drop dari pusat sebagai Gubernur Lampung pertama. Kala itu saya masuk serambinya Soekarno yang sudah ditunggu oleh orang-orang PKI. Jadi dia itu dipengaruhi PKI. Sukarno terjepit di pusat. Hasil pemilihan dikirim ke pusat. Saya dipanggil Soekarno, saya dikatakan, dek sambil ditepuk kamu pantas. Tapi bagaimana ya? Saya harap adek mengerti saya. Saya nggak ada permasalahan, apa kata Bapak, itu saya ikuti. Saya sebab mendengar sehingga timbul hal itu yang justru untuk menolong Pak Karno. (Wawancara, 1 Oktober 2009)

Oleh sebab karena hal itu adalah permintaan resmi Soekarno kepada dirinya maka pada saat itu R.A Zulkifli Warganegara tidak membantah keinginan Soekarno sehingga persoalan itu dianggap selesai oleh R.A Zulkifli Warganegara.

Pada era orde lama dalam konteks elit Islam di Lampung, setelah Masjumi dibekukan oleh Soekarno peran dari elit-elit Islam dalam sistem politik banyak dilakoni oleh NU seperti apa yang diungkapkan oleh Pangeran Nur "Saya kurang jelas kalau di tingkat pusat, kalau di tingkat Lampung ini NU pada waktu itu yang agak tenar. Sebab pada waktu itu anggota DPRnya kebanyakan dari NU, PNI, PSII, IKIP, Masyumi pada waktu itu sudah dibekukan."

Dalam konteks yang lain, pertarungan antar elit relatif tidak seperti halnya sekarang yang tidak dapat berkompromi dan seperti halnya yang digambarkan oleh Arifin 
Nitipradjo Tegamoan, Arifin mengungkapkan bahwa pada masa itu ketika PNI dibawah kepemimpinan Gele Harun proses ideologisasi yang dilakukan PKI tidak mempengaruhi PNI, walaupun secara ideologi hal itu memungkinkan karena kedekatan elit-elit PNI pusat dengan elit PKI. Selain menggunakan pola ideologisasi pendekatan yang dilakukan PKI juga dengan mengajak pemuda-pemuda kala itu berolahraga seperi halnya yang dikatakan oleh Arifin Nitipradjo Tegamoan:

Elit-elit partai itu pada waktu itu ya, kebetulan pada waktu terakhir Pak Alamsyah ini PNI pada waktu itu ya sudah hampir meletakkan jabatannya, sehingga akan diganti oleh Pak Gele Harun. Nah, pada waktu itulah juga kebetulah Pak Gele Harun tidak bisa terpengaruh oleh PKI ini, sehingga masih tegar dan PNI masih tetap dominan. Itu sebabnya sehingga tidak bisa dikuasai oleh PKI seluruhnya. Massa PKI dominan sekali terutama umpamanya di Bandar Lampung, bisa saya kasih contoh, kebetulan meskipun saya ada di Jakarta pada waktu itu. Saya tahu betul, pemudapemuda, terutama anak-anak dari Kampung Sawah, lapangan bola Brebes itu boleh dikatakan sangat dikuasai oleh PKI semuanya. Itu hampir semulah anak-anak muda, semua dikuasai oleh PKI. (Wawancara, 1 Desember 2009)

Seperti yang digambarkan oleh berbagai narasumber dalam penelitian ini terlihat sekali bahwa pertarungan elit dimasa orde lama model pertarungan politik aliran yang mana terlihat sekali kompetisi antar elit itu mengacu pada kepentingan ideologis, bukan sebuah transaksional politik spserti halnya sekarang. Akan tetapi walaupun itu adalah sebuah pertarungan politik aliran akan tetapi tetap saja kompromi dan fatsoen atau etika politik menjadi acuan kompetisi. Seperti halnya yang diungkap oleh Arifin Nitipradja Tegamoan:

Ya, sesungguhnya, macam di daerah ya, terutama di daerah, kalau melihat elit-elit politik atau ketuaketuanya itu, seolah-olah, ya karena hubungan baik barangkali ya. Cakarcakaran itu sangat berkurang sekali. Meskipun pandangan mereka lain2. Tetapi, kalau sebangsa cakar-cakran tidak ada. Ditambah lagi, usulan karena adanya perjuangan untuk memperjuangkan Lampung menjadi propinsi. Sehingga, mereka yang dipelopori oleh Ketua PNI, sehingga merka kompak sekali untuk hal itu. Jadi kami, yang diluar Lampung, pada waktu itu, cukup mendukung saja. Aduh, jauh betul. Perbedaannya terutama hubungan antar partai itu berdasarkan hubungan baik. Ya, aman-aman saja. Mungkin karena dasarnya hubungan baik, ya, kekeluargaan. Ide itu soal kedua, yang pertama itu hubungan baik, kekeluargaan. Sekarang ide duluan, harus menang juga, itu idenya harus menang. Itu yang menyebabkan jadi cakar-cakaran terus. (Wawancara, 1 Desember 2009)

Hal kontras terjadi dalam politik Lampung kontemporer, ketika persaingan politik aliran sudah tidak mengemuka lagi maka konflikkonflik politik di daerah ini sering sekali disebabkan oleh persoalan yang tidak substantif yang sebenarnya mudah untuk diselesaikan. 


\section{Simpulan}

1. Terdapat perubahan mendasar konflik dan kontestasi elit politik lokal di Lampung pada era reformasi jika dibandingkan dengan era orde lama, pada era reformasi konflik lebih pada persoalan kepentingan antar aktor politik sedangkan di era orde lama konflik lebih pada konflik yang disebabkan oleh politik aliran. Karena konflik di era reformasi ini lebih bersifat konflik kepentingan aktor maka model-model penyelesaian transaksional lebih mengemuka dibandingkan dengan model konsensus atau mufakat seperti di era orde lama.

2. Kontestasi elit politik di Lampung pada era Orde Lama tahun 1945 sampai dengan 1964 diwarnai oleh 3 (tiga) ideologi besar yaitu Nasioalis, Islam dan Komunisme.

3. PNI, PKI, Masjumi dan NU adalah partai yang mendominasi parlemen lokal Lampung di era orde lama.

4. Ketika Masjumi dibekukan oleh Soekarno, maka NU yang kemudian menjadi representasi dominan basis massa Islam dalam sistem politik.

5. Konflik elit politik lokal Lampung di era orde lama merepresentasikan konflik politik aliran Indonesia pada masa yaitu antara pengikut ideologi Nasionalis, Islam dan Komunisme, akan tetapi terjalnya konflik politik aliran dapat diselesaikan dengan proses negosiasi dan mufakat.

\section{Daftar Pustaka}

Burhan Bungin.2001. dalam Metode Penelitian Kualitatif

(Aktualisasi Metodelogis ke Arah Ragam Varian Kontemporer). PT Raja Grafindo Press. Jakarta.

Dewan Harian Angkatan 45. 1994. Buku I-III: Untaian Bunga Rampai Perjuangan di Lampung. PT Agung Sidapore. Jakarta

Giddens, Anthony. 1985. Kapitalisme dan Teori Sosial Modern (Penerj. Suheba Kramdibrata). Jakarta : UIPress

Hadari Nawawai. 1987. dalam. Metode Penelitian Bidang Sosial. UGM Press. Yogyakarta

Ida, Laode. 2002. Otonomi Daerah, Demokrasi Lokal \& Clean Government. Jakarta: PSPK

Anonim, 100 Tokoh Terkemuka Lampung. Lampung Post. 2008

Arif Mahkya. Menyambut Dewan Baru 6 Sepetember 2004 di Lampung Post

Salim Alatas. Politik Aliran dalam Pemilu 2009 